Gerardo Aniano C. Dimaguila, MD, MPH

Emmanuel S. Samson, MD

Department of Otolaryngology

Head and Neck Surgery

Pamantasan ng Lungsod ng Maynila

Ospital ng Maynila Medical Center

\section{Oral Propranolol Therapy for Benign Capillary Hemangiomas in a Series of Adult and Pediatric Patients}

\begin{abstract}
Objective: To describe outcomes of oral propranolol therapy in a series of adult and pediatric patients diagnosed with benign capillary hemangioma of the head and neck.
\end{abstract}

\section{Methods:}

\section{Design: $\quad$ Prospective Case Series \\ Setting: $\quad$ Tertiary Government Teaching Hospital}

Participants: Ten (10) patients representing all patients clinically diagnosed with benign capillary hemangioma of the head and neck enrolled in the study from 2012 to 2015.

Results: Two (2) adults and eight (8) children were enrolled in the study. Although a decrease in lesion size was observed in half of the participants starting at three months, only one (1) attained complete resolution of the lesion-- a 12-year-old girl with hemangioma of the right parotid gland that attained clinical resolution of symptoms after four months of treatment. The remaining nine out of ten (9/10) participants did not attain complete clinical resolution; but there was a decrease in lesion size in four (4) of these participants. For the remaining five (5) participants, there was neither a decrease nor an increase in lesion size. Altogether, of the two adult participants, only one responded to therapy while only 4 out of 8 pediatric participants responded to therapy. There were no noticeable differences between adult and pediatric patients in terms of resolution and plateau. Aside from mild bradycardia expected with propranolol, no adverse reactions were observed during the course of treatment.

Conclusions: Although half of our participants responded to oral propranolol therapy whether these observations may be attributable to oral propranolol alone cannot be concluded.

Keywords: hemangioma, capillary; hemangioma; propranolol administration, oral; propranolol

Benign capillary hemangiomas are one of the most common benign tumors of childhood with an incidence at birth of $1-2 \%$ in white Caucasians, Asians and Blacks reaching almost $10 \%$ in the former but significantly lower in the latter two by the end of the first year. ${ }^{1}$ The incidence is higher in preterm infants less than $1 \mathrm{~kg}$ reaching nearly $30 \%{ }^{1}$

Several trials have demonstrated the efficacy of oral propranolol therapy in treating infantile hemangiomas. ${ }^{2-6}$ However, despite its anecdotal use, we were not aware of evidence supporting the use of oral propranolol for treating hemangiomas in older children and adults with negative results from a search of PubMED, HERDIN and Google Scholar using the keywords "hemangioma 
capillary" "hemangioma" "propranolol administration oral" and "propranolol."

With the question; "will oral propranolol still be effective in treating hemangiomas in older children and adults," this study aims to describe outcomes in a series of adult and pediatric patients with benign capillary hemangioma of the head and neck.

\section{METHODS}

With institutional review board approval, this prospective case series considered all patients seen at the out-patient or emergency department of our tertiary government hospital, who were clinically diagnosed with benign capillary hemangioma of the head and neck from 2012 to 2015. To be excluded were patients clinically diagnosed with capillary hemangioma who had undergone other forms of treatment such as, but not limited to use of intralesional sclerosing agents, oral or topical corticosteroids, or recurrence after prior surgical intervention; patients or patients parents/ guardians who would not consent to undergo oral propranolol therapy; and patients in whom oral propranolol therapy was contraindicated or in whom the adverse effects of oral propranolol would greatly outweigh the benefits such as those suffering from asthma.

With written informed consent (and assent, where applicable), propranolol $40 \mathrm{mg}$ and $10 \mathrm{mg}$ tablets were used. For adult patients, propranolol was administered orally in three (3) divided doses daily with reassessment planned weekly for the first month followed by 2-month intervals for a year. For pediatric patients, paper tablets- finely ground powder that can be dissolved in liquid were used. A written prescription with instructions to the pharmacist to prepare propranolol paper tablets in the computed dose was given to the patient's parent/ relative/guardian so that they could purchase this at the pharmacy. Oral propranolol was given at a dose of $2 \mathrm{mg} / \mathrm{kg} /$ day in three (3) divided doses daily with reassessment planned weekly for the first month followed by 2-month intervals for a year.

Prior to initiation of therapy, each patient was evaluated by a cardiologist to obtain baseline data and to ascertain that there were no contraindications to the proposed therapy. Patients were observed in the emergency room for 24 hours at the start of therapy with heart rate and blood pressure monitored by the hour. After the first 24 hours, the patients were then discharged and instructed to take propranolol orally every 8 hours with daily visits for the first week followed by weekly visits thereafter.

On each follow-up visit, either author evaluated the lesion, focusing on such gross features as size and boundaries, color, induration and consistency. Measurements were taken using a Vernier caliper $150 \mathrm{~mm}$ (Acosta, Taiwan) and cloth tape measure (Goldfish, China) and findings were manually recorded with pen and paper. Photographs were taken using a 2007 Sony Ericsson W960 3-Mega Pixel Auto Focus LED Flash Camera (Sony Ericsson, China).

Qualitative final assessments regarding decrease in lesion size and boundaries, change in color and change in consistency and induration were subjectively classified "yes" or "no" by both authors in consensus based on the recorded measurements and photographs.

\section{RESULTS}

A total of 10 patients, two (2) adults (aged 23 and 31, respectively) and eight (8) pediatric patients (aged 3 months to 13 years) were enrolled in the study with none excluded. Only one (1) attained complete resolution of the lesion; a 12-year-old female diagnosed with hemangioma of the right parotid gland that attained clinical resolution of symptoms after four months of treatment. (Figure 1) Including this girl, five of the patients were lost to follow up less than six (6) months after initiating treatment (two at the $2^{\text {nd }}$ month, one at the $3^{\text {rd }}$ month and two at the $4^{\text {th }}$ month, respectively).

Although the remaining nine out of ten (9/10) patients did not attain complete clinical resolution, there was a decrease in lesion size in four (4) participants starting at three months.

One of these, a 31-year-old woman with multiple small capillary hemangiomas of the dorsum of the tongue was observed until the $8^{\text {th }}$ month of therapy. There was marked decrease in the size and number of lesions since the start of the therapy prominently noticed around the $3^{\text {rd }}$ month with markedly less discoloration surrounding the lesions. However, there was no noticeable change in the size of the lesions after the $5^{\text {th }}$ month. (Figure 2)

Another, a four-year-old girl with a lesion of the anterior third of the tongue was observed to have a decrease in lesion size by the $12^{\text {th }}$ month of therapy with plateau occurring by the end of the $15^{\text {th }}$ month. She was initially seen when she was still a year old and presented with a purplish red lesion involving almost the entire dorsum of the tongue. After 12 months of therapy, the lesion started to shrink with areas that started sloughing off. It assumed a wrinkled, prune-like appearance and showed signs of resolving. However by the $15^{\text {th }}$ month, the lesion regained its purplish color and remained unchanged until the patient was last seen at age 4. There were no reported difficulties in speech and feeding. (Figure 3)

Also included in this group was an 8-year-old boy with capillary hemangioma of the right cheek and upper lip. The patient's lesion showed signs of regression after four months of therapy. The most noticeable change was a decrease in discoloration around the right cheek as well as a decrease in the swelling around the right upper lip after 6 months of treatment. (Figure 4) 
The last patient to show a decrease in lesion size was an 11-year-old girl with hemangioma of the right cheek and upper lip with involvement of the buccal mucosa noted around the $3^{\text {rd }}$ month of therapy. Also noteworthy was the clearing up of the buccal mucosa involvement to almost near-normal. However, rapid plateau was attained with no decrease in lesion size after the $5^{\text {th }}$ month. She was on continued oral propranolol therapy for 12 months before being lost to follow up. (Figures 5 and 6)

Altogether, of the two adult participants, only one responded to therapy while only 4 out of 8 pediatric participants responded to therapy. There were no noticeable differences between adult and pediatric patients in terms of resolution and plateau. Aside from mild bradycardia expected with propranolol, no adverse reactions were observed during the course of treatment.

Table 1. Summarizes our findings

\begin{tabular}{|c|c|c|c|c|}
$\begin{array}{c}\text { Patient } \\
\text { Age/ Sex }\end{array}$ & $\begin{array}{c}\text { Duration of } \\
\text { participation/ } \\
\text { duration of oral } \\
\text { propranolol therapy } \\
\text { (months) }\end{array}$ & $\begin{array}{c}\text { Decrease } \\
\text { in Lesion } \\
\text { Size/ } \\
\text { Boundaries? } \\
\text { (Yes/No) }\end{array}$ & $\begin{array}{c}\text { Change } \\
\text { in Color? } \\
\text { (Yes/No) }\end{array}$ & $\begin{array}{c}\text { Change } \\
\text { in } \\
\text { Consistency } \\
\text { Induration } \\
\text { (Yes/No) }\end{array}$ \\
\hline $23 / \mathrm{F}$ & 2 months & No & No & No \\
$13 / \mathrm{F}$ & 2 months & No & No & No \\
$6 \mathrm{mos} / \mathrm{M}$ & 3 months & No & No & No \\
$1 / \mathrm{M}$ & 4 months & No & No & No \\
$12 / \mathrm{F}$ & 4 months & Yes & Yes & Yes \\
$3 \mathrm{mos} / \mathrm{F}$ & 6 months & No & No & No \\
$8 / \mathrm{M}$ & 6 months & Yes & Yes & Yes \\
$31 / \mathrm{F}$ & 8 months & Yes & Yes & Yes \\
$11 / \mathrm{F}$ & 12 months & Yes & Yes & Yes \\
$1 / \mathrm{F}$ & 36 months & Yes & Yes & Yes \\
\hline
\end{tabular}

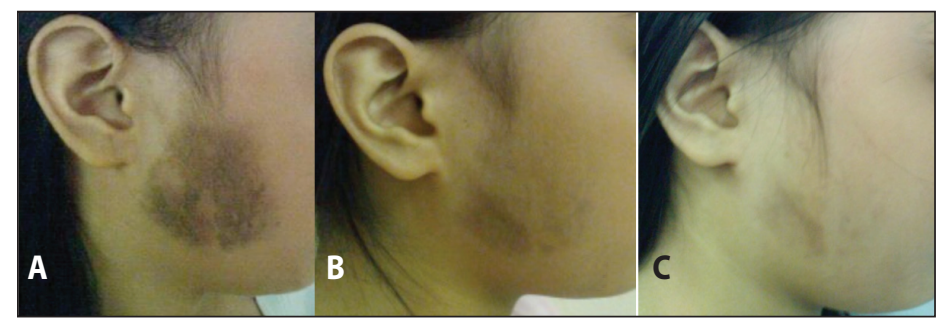

Figure 1. A. Patient on day 1 of oral propranolol therapy B. Day 78 (end of 2nd month) C. Day 121 (end of 4th month).

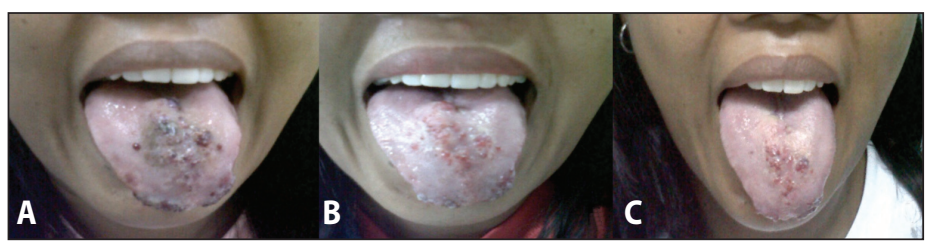

Figure 2. A. Patient on day 1 of therapy B. after the 64th day of therapy (2 months) and C. after 150 days of therapy (5 months). Note little change in the size of the lesion in figures $B$ and $C$.
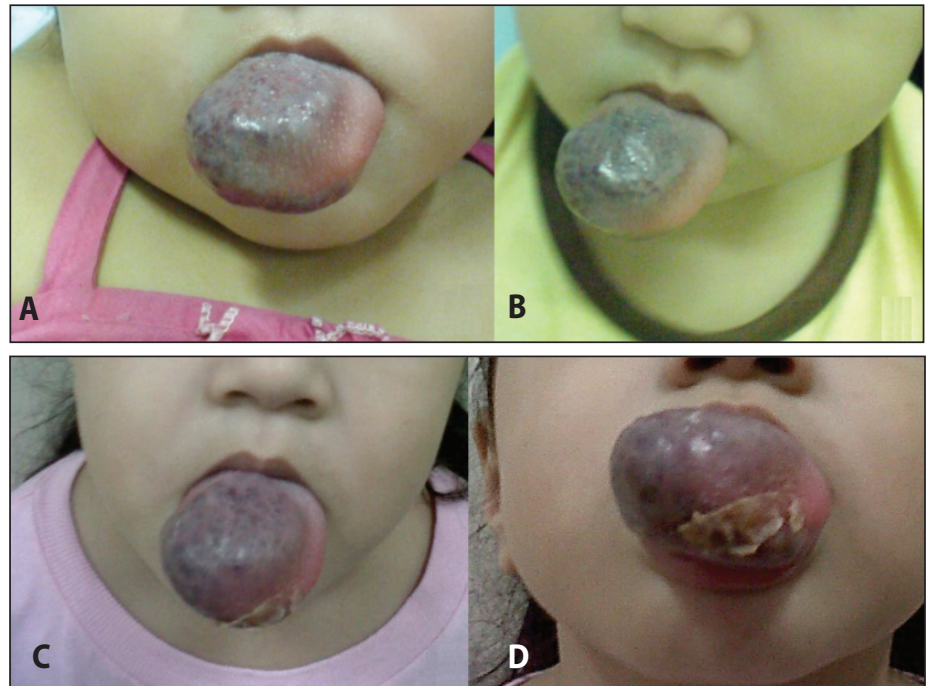

Figure 3. A. Patient on day 0 of therapy B. on day 450 ( 15 months) of therapy; C. After 720 days (24 months); D. There was almost no change in size of the lesion from 15 months to 24 months except for some areas which had sloughed off.

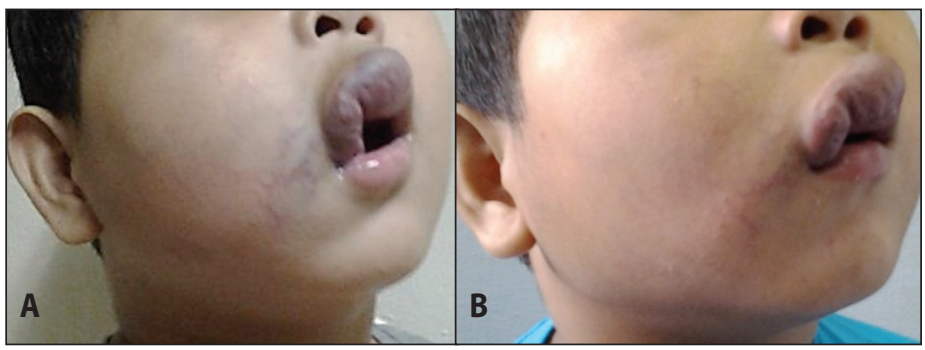

Figure 4. A. Day 0 of therapy B. Day 120 (4th month) of therapy; note the decrease in discoloration of the right cheek and hemiface.

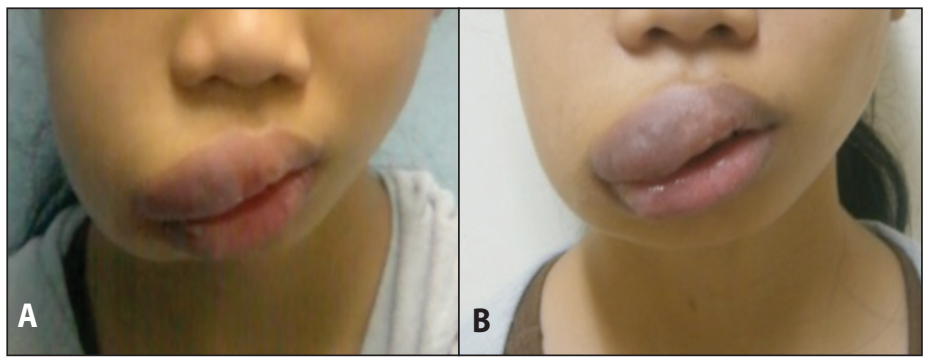

Figure 5. A. Day 0 of therapy B. At approximately 120 days of therapy (4th month).

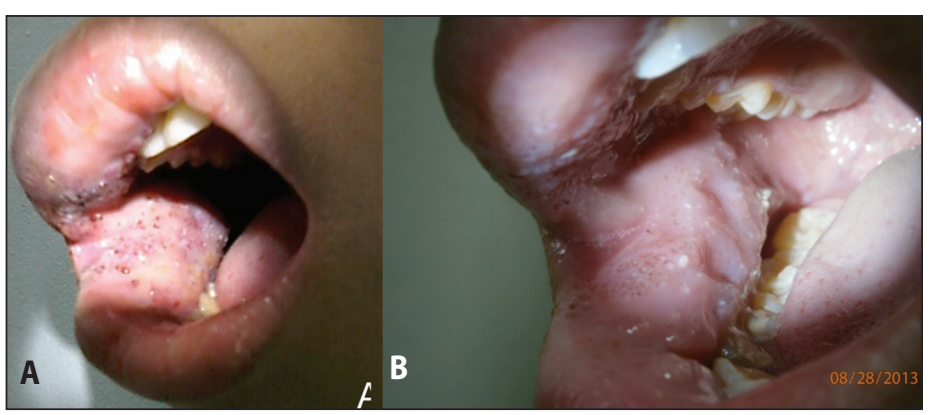

Figure 6. A. Buccal mucosa involvement of our patient depicted above at day 0 B. Day 120 (4 months), Notice the decrease in the small maculo-papular lesions to near normal mucosa by the 4th month. 


\section{DISCUSSION}

Out of the ten (10) patients who were enrolled in the study, only half or five (5) showed a decrease in the size of the lesion-- one (1) adult and four (4) children. The remaining half did not show any changes in the size of the lesion. Given the number of reports on the success of oral propranolol therapy in infantile hemangiomas, ${ }^{2-6}$ we were expecting a high rate of resolution among older children and adults as well. As our results show though, only half of the patients responded (and most, only partly) to oral propranolol therapy. Getting to the bottom of the whys and why nots entail taking a look at how propranolol acts on infantile hemangiomas.

The exact mechanism of hemangioma growth and regression is not clearly understood. Hemangiomas are a mixture of clonal endothelial cells, pericytes, dendritic cells and mast cells. ${ }^{7}$ Proangiogenic factors such as basic fibroblast growth factor (bFGF) and vascular endothelial growth factor (VEGF) have been theorized to play a role in the proliferation and growth of hemangiomas. ${ }^{7}$ Factors that affect involution are downregulation of angiogenesis and upregulation of angiogenesis inhibitors, ${ }^{7,9}$ the mechanism proposed by some for the success of beta blockers in triggering involution. ${ }^{8}$ These studies have demonstrated a triggered apoptosis of capillary endothelial cells in adult rat lung tissue with the use of propranolol and documented a decrease in locally produced VEGF-1 in hemangiomas upon initiation of propranolol. ${ }^{8}$ Since VEGF-1 is a proangiogenic factor, its inhibition results in involution. Based on these studies, we thought oral propranolol therapy should work on hemangiomas whether infantile among older children or among adults. Yet, only half of the patients in our study responded to therapy.

An important limitation of our study may have been our failure to distinguish 'true' infantile hemangiomas from other vascular anomalies and malformations. ${ }^{711}$ Other studies that have employed oral propranolol therapy would not recommend using it on other vascular anomalies. ${ }^{10}$ These anomalies behave differently from infantile hemangiomas in that they are not affected by angiogenic factors and can be affected by other factors such as trauma, infection and hormones. ${ }^{7}$ In retrospect, we could have been dealing with other forms of vascular anomalies in those patients who did not respond to oral propranolol therapy. We recommend that more attention be given to correctly diagnosing infantile hemangiomas in distinction from other vascular anomalies.

As for the participants who did respond to therapy, we must consider whether the resolution was indeed due to propranolol therapy or to spontaneous involution. It is well documented that $90 \%$ of hemangiomas involute by age 10 years while those that do not involute beyond 10 years have a greater chance of persisting throughout adulthood.? Five (5) of our patients presented with a hemangioma persisting beyond the $10^{\text {th }}$ year of life and the probability of spontaneous involution coinciding with the initiation of propranolol therapy seems slim. In these cases, it would be tempting to consider that the resolution and/or diminution of our patients' lesions was an effect of propranolol therapy. However, our small sample with cursory documentation and observer bias and no comparator group (inherent to the design of a case series) are limitations that do not allow us to jump to any such conclusions. Future, better-designed studies may avoid these limitations and possibly shed light on our research question.

Our experience with these ten (10) patients has not answered the question of whether oral propranolol therapy will have a good outcome on older children and adults. Although half of our participants responded to oral propranolol therapy whether these observations may be attributable to oral propranolol alone cannot be concluded.

\section{REFERENCES}

1. Antaya RJ. Infantile Hemangioma. In James WD, Wells MJ, Perry V (editors). Medscape. [updated 2017 Oct 02; cited 2017 Oct 4] Available from: http://emedicine.medscape.com/ article/1083849-overview\#showall.

2. Leaute-Labreze C, Dumas de la Roque E, Hubiche T, Boralevi F, Thambo JB, Taieb A. Propranolol for Severe Hemangiomas of Infancy. Letters to the Editor. N Engl J Med. 2008 Jun 12; 358(24): 2649-51. [updated 2008 Jun 12; cited 2012 Aug 20] Available from: http:// authors.nejm.org/ nengljmed358;24. DOI: 10.1056/NEJMc0708819; PMID: 18550886.

3. Zvulunov A, McCuaig C, Frieden IJ, Mancini AJ, Puttgen KB, Dohil M, et al. Oral propranolol therapy for infantile hemangiomas beyond the proliferation phase: A multicenter retrospective study. Pediatr Dermatol. 2011 Mar-Apr; 28(2): 94-98. DOI: 10.1111/j.1525-1470.2010.01379.x; PMID: 21362031.

4. Celik A, Tiryaki S, Musayev A, Kismali E, Levent E, Erqun O. Propranolol as the first line therapy for infantile hemangiomas: Preliminary results of two centers. J Drugs Dermatol. 2012 Jul; 11(7):808-11. PMID: 22777220.

5. Schupp CJ, Kleber JB, Gunther P, Holland-Cunz S. Propranolol therapy in 55 infants with infantile hemangioma: dosage, duration, adverse effects and outcome. Pediatr Dermatol. 2011 Nov-Dec; 28 (6):640-4. DOI: 10.1111/j.1525-1470.2011.01569.x; PMID: 21995836.

6. Al Dhaybi R, Superstein R, Milet A, Powell J, Dubois J, McCuaig C, Codere F. Treatment of periocular infantile hemangiomas with propranolol: case series of 18 children. Ophthalmology. 2011 Jun; 118(6): 1184-8. DOI: 10.1016/j.ophtha.2010.10.031; PMID: 21292326.

7. Darrow DH, Greene AK, Mancini AJ, Nopper AJ. Diagnosis and Management of Infantile Hemangioma. Pediatrics. 2015 Oct; 136(4): e1060-e1104. [cited 2017 Oct 4]. Available from: http://pediatrics.aappublications.org/content/136/4/e1060. DOI: 10.1542/peds.2015-2485.

8. Sommers-Smith S, Smith DM. Beta blockade induces apoptosis in cultured capillary endothelial cells. In Vitro Cell Dev Biol Anim. 2002 May; 38(5):298-304. DOI: 10.1290/1071-2690(2002)038<0 298:BBIAIC>2.0.CO;2; PMID: 12418927.

9. Zimmerman AP, Wiegand S, Werner JA, Eivazi B. Propranolol therapy for infantile hemangiomas: review of the literature. Int J Pediatr Otorhinolaryngol. 2010 Apr; 74(4):338-42. DOI: 10.1016/j. ijporl.2010.01.001; PMID: 20117846.

10.Popoiu CM, Stanciulescu C, Popoiu A, Nyiredi A, RE lacob PC, David VL, et. al., Treatment of Vascular Anomalies in Children: Pros and Cons. Jurnalul Pediatrului. 2014 Jul-Dec; XVII (67-68) 37-41. [cited 2017 Oct]. Available from: http://www.jurnalulpediatrului.ro/pages/arhiva/6768/67-68-08.pdf

11.Richter GT, Friedman AB. Hemangiomas and Vascular Malformations: Current Theory and Management. International Journal of Pediatrics. Volume 2012 (2012): Article ID 645678. 10 pages. [cited 2017 Oct 4]. Available from: https://www.hindawi.com/journals/ ijpedi/2012/645678/. DOI: http://dx.doi.org/10.1155/2012/645678. 